\title{
INOCULATION OF Lacazia Ioboi INTO THE SUBCUTANEOUS TISSUE OF THE HAMSTER CHEEK POUCH
}

Diltor Vladimir Araujo OPROMOLLA(1) \& Maria Esther Salles NOGUEIRA(2)

\begin{abstract}
SUMMARY
The subcutaneous tissue of the hamster cheek pouch, a site of immunologic privilege, has been used to investigate the potential infectivity of different types of parasites. It has been demonstrated that the implantation of fragments of lesions induced by the fungus Lacazia loboi, the etiologic agent of Jorge Lobo's disease, into the subcutaneous tissue of the hamster cheek pouch resulted in parasite multiplication and dissemination to satellite lymph nodes ${ }^{16}$. Here we describe the evolution of lesions induced by the inoculation of the isolated fungus into this immunologically privileged site. The morphology of the inflammatory response and fungal viability and proliferation were evaluated. Inoculation of the fungus into the cheek pouch induced histiocytic granulomas with rare lymphocytes. Although fungal cells were detected for a period of up to 180 days in these lesions, the fungi lost viability after the first day of inoculation. In contrast, when the parasite was inoculated into the footpad, non-organized histiocytic lesions were observed. Langhan's giant cells, lymphocytes and fungal particles were observed in these lesions. Fungal viability was observed up to 60 days after inoculation and non-viable parasites were present in the persistent lesions up to 180 days post-inoculation. These data indicate that the subcutaneous tissue of the hamster cheek pouch is not a suitable site for the proliferation of Lacazia loboi when the fungus isolated from human tissues is tested.
\end{abstract}

KEYWORDS: Lacazia loboi; Granuloma; Cheek Pouch; Hamster.

\section{INTRODUCTION}

Jorge Lobo's disease ${ }^{12}$ is a human endemic mycosis of chronic evolution diagnosed in the Brazilian and Colombian Amazon. The disease

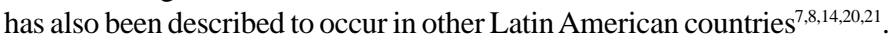
A keloid-like lesion on the skin is the foremost sign of the disease ${ }^{10}$ and the etiological agent, Lacazia loboi (L. loboi $)^{1}$, is found in large numbers inside macrophages.

One of the major limitations of the understanding of the pathogeny of Jorge Lobo's disease is the fact that the fungus has not yet been cultivated in vitro and experimental inoculations in an attempt to reproduce the disease have been unsatisfactory ${ }^{4,13,17,18}$. Nevertheless, SAMPAIO \& DIAS, $1970^{16}$ demonstrated fungal proliferation and dissemination to satellite lymph nodes when fragments of lesions obtained from infected patients were implanted into the subcutaneous tissue of the hamster cheek pouch, an immunologically privileged site.

Based on the observations of SAMPAIO \& DIAS ${ }^{16}$, we decided to re-evaluate the evolution of infection induced by $L$. loboi inoculated into the subcutaneous tissue of the hamster's cheek pouch using now purified isolates of the fungus obtained from patient lesions.

\section{MATERIAL AND METHODS}

1. Animals: 150 hamsters (Mesocricetus auratus) obtained from the "Instituto Lauro de Souza Lima" were inoculated. However, only 32 animals which developed well defined lesions were selected for the experimental group. The animals were all healthy adult males weighing $80-120 \mathrm{~g}$, housed in appropriate plastic boxes, receiving commercial food and water ad libitum.

2. Organisms: L. loboi was obtained from lesions of six patients with Jorge Lobo's disease. Fragments of lesions obtained after patient agreement were homogenized in $0.85 \%$ sterile saline solution (SSS) and fungal concentration was determined using a Neubauer hemocytometer. Results were expressed as absolute numbers. Fungal viability was determined using vital staining with fluorescein diacetate/ethidium bromide according to the technique proposed by VILANI-MORENO \& OPROMOLLA $^{22}$. Suspensions of Paracoccidioides brasiliensis, strain 18, obtained from the Department of Pathology, School of Medicine "Júlio de Mesquita Filho", Botucatu Campus, were used as controls.

3. Inoculations: The animals were divided at random into two groups (A and B). Twenty animals from Group A were inoculated with $0.1 \mathrm{ml}$

(1) Instituto Lauro de Souza Lima, Research, Training and Teaching Division. Bauru, São Paulo, Brazil.

(2) Instituto Lauro de Souza Lima, Immunology Sector, e-mail: imulogia@ilsl.br

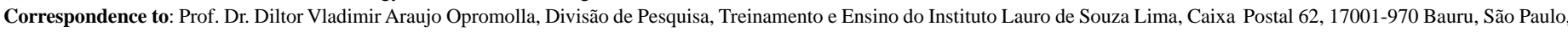
Brasil. Phone: 0XX14 221-5860, extension 296. Fax: 0XX14 221-5914. e-mail: pesquisa@ilsl.br 
of a suspension of $5 \times 10^{6} \mathrm{~L}$. loboi particles with $55 \%$ viability into the subcutaneous tissue of the distal portion of the right and left cheek pouches. After 24 and 48 hours, and after 7, 15, 30, 60, 90, 120, 150 and 180 days of fungal inoculation, two animals were sacrificed in a chamber saturated with ethyl ether vapor. Group B, consisting of 12 animals, was inoculated with $0.1 \mathrm{ml}$ of a $L$. loboi suspension $\left(5 \times 10^{6}\right.$ particles with $55 \%$ viability) into the subcutaneous tissue of both the right and left rear footpads. Two animals were sacrificed as above 30, 60, 90, 120, 150 and 180 days after the fungal inoculation.

The distal portion of the right cheek pouches and the footpads of the inoculated animals (Group A and B) were removed, fixed in 10\% formalin, and embedded in paraffin. Histological sections were stained with hematoxylin-eosin ${ }^{11}$ and Gomori-Grocott's methenamine-silver ${ }^{9}$.

The left cheek pouches and footpads from both groups (A and B) were homogenized in $0.85 \%$ SSS and fungal viability and concentration were determined as described.

\section{RESULTS}

\section{CHEEK POUCH}

Fungal viability in these lesions was $3 \% 24$ hours after inoculation and $0 \%$ up to the end of the experiment. Fungal concentration decreased from $3.0 \times 10^{6}$ to $4.5 \times 10^{3} / \mathrm{ml}$ after 180 days.

Histological sections of the cheek pouch of animals sacrificed after 24 hours showed an acute inflammatory infiltrate predominantly composed of neutrophils. In the central area of the lesions, small numbers of fungi were observed, some with pink material in their inner part and others resembling empty capsules. Well and poorly stained fungi were observed in the Gomori's methenamine-silver stained sections. Clusters of brown granules were also observed in the tissue. Seven days after fungal inoculation, a neutrophilic infiltrate and macrophages with vesicular cytoplasm and nuclei were observed. Fifteen days after inoculation, the lesions were loose and composed of an extensive infiltrate consisting of macrophages, small numbers of giant cells, rare lymphocytes and neutrophils. A large number of fungi, most of them resembling an empty capsule, were observed in these lesions. In Gomori stained preparations, poorly stained fungi and a large quantity of granular, fine and brownish material similar to the fungal walls were observed. This material, suggestive of fungal destruction, will be referred to as argentophilic dust. Thirty days after inoculation the lesion was moderate, loose, poorly delimited and predominantly consisting of Langhan's giant cells and histiocytes with abundant lacy cytoplasm and condensed nuclei. Lymphocytes, neutrophils and eosinophils were rare in these lesions (Fig. 1a). In Gomori's preparations, among a few well-stained fungi, large quantities of poorly stained and fragmented parasites were observed. Distinctive and abundant argentophilic dust was also observed inside macrophages and giant cells, suggesting intracytoplasmic fungal destruction (Fig. 1b). After 150 days of infection, the lesions were smaller and formed almost exclusively by cells with lacy cytoplasm and compact, small, clustered nuclei. Gomori's staining showed poorly stained fungi and a large amount of argentophilic dust dispersed in the lesion. After 180 days of infection, the lesions were similar to those of 150 days although they were smaller, with a moderate cellular infiltrate. Histiocytic cells infiltrating these lesions presented a lacy and basophilic cytoplasm.
A large number of them showed a syncytial aspect since no membranes were present to separate them (Fig. 1c). Gomori's staining showed large amounts of argentophilic dust dispersed in the lesions (Fig. 1d).

\section{FOOTPAD}

After 30 days of fungal inoculation into the footpad of the animals, histological sections revealed a histiocytic cell infiltrate with two, three or four nuclei, typical foreign body giant cells and syncytial formations were observed. Gomori's staining evidenced a large number of fungi, most of them well stained, and a small accumulation of argentophilic material. After 60 days of inoculation, the infiltrate was composed by aggregates of histiocytic cells and some giant cells. Lymphocytes were present in small numbers. Well-stained fungi and argentophilic dust in an amount proportional to the number of poorly stained fungi were seen. Well-stained gemmation forms of the fungus were also observed. After 120 days of fungal inoculation, the infiltrate was smaller and composed by histiocytic cells and foreign body giant cells. Areas with a larger number of mononuclear cells, including some plasmocytes, were also observed. After Gomori's staining, small quantities of fungi were poorly stained and surrounded by large amounts of argentophilic dust. After 180 days of infection, the infiltrate was discrete and composed by histiocytic cells, Langhan's giant cells, and few mononuclear cells (Fig. 2a). Using Gomori's staining, a few poorly stained fungi surrounded by large quantities of argentophilic dust were observed (Fig. 2b).

\section{DISCUSSION}

Hamsters have a pair of cheek pouches that open into the oral cavity and expand dorso-caudally under the shoulder skin. They are lined by a stratified epithelium and supported by dense connective tissue, which covers a loose, highly vascularized connective tissue. This loose or areolar tissue connects the external wall of the pouches to adjacent structures, allowing easy eversion of the pouch in anesthetized animals ${ }^{5}$.

The hamster's cheek pouch is considered an immunologically privileged site since heterologous tissues implanted at this site are not immunologically rejected. The absence or paucity of lymphatic drainage in this area is one of the explanations for the phenomenon ${ }^{19}$. Based on this property, the inoculation of an infectious agent at this site would theoretically favor the multiplication of the parasite considering the absence of a specific immune response against parasite antigens. On the basis of this hypothesis, the hamster cheek pouch could be used to investigate the viability and possible infectivity of non-cultivable microorganisms. This approach has been used to investigate different aspects of parasite infection $2,3,15,16,19$.

In this respect, SAMPAIO \& DIAS ${ }^{16}$ were the first to investigate the behavior of $L$. loboi inoculated into the subcutaneous tissue of the cheek pouch of hamsters. Some of the observations made by these authors conflict with the data herein presented. In the experiments of SAMPAIO \& DIAS 16 "live" fungi were detected after 180 days of inoculation while in our experiments only $3 \%$ viable parasites were detected 24 hs post inoculation in the pouch and $0 \%$ viable fungi were detected 180 days after inoculation. This discrepancy might be due to the differences in the technique of parasite inoculation. We isolated the parasites before inoculation while SAMPAIO \& DIAS ${ }^{16}$ implanted fragments of lesions collected from patients. On the other hand, it is important to observe 


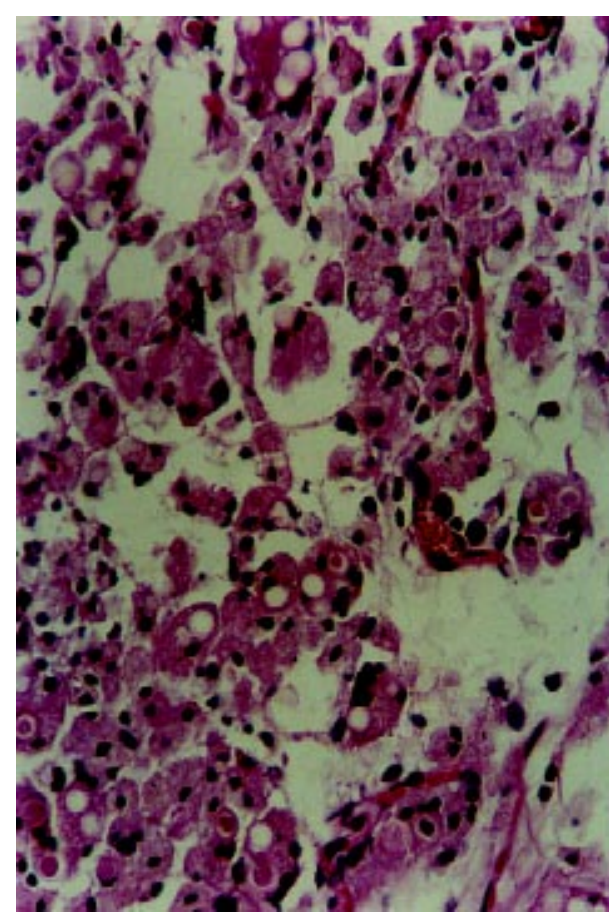

A

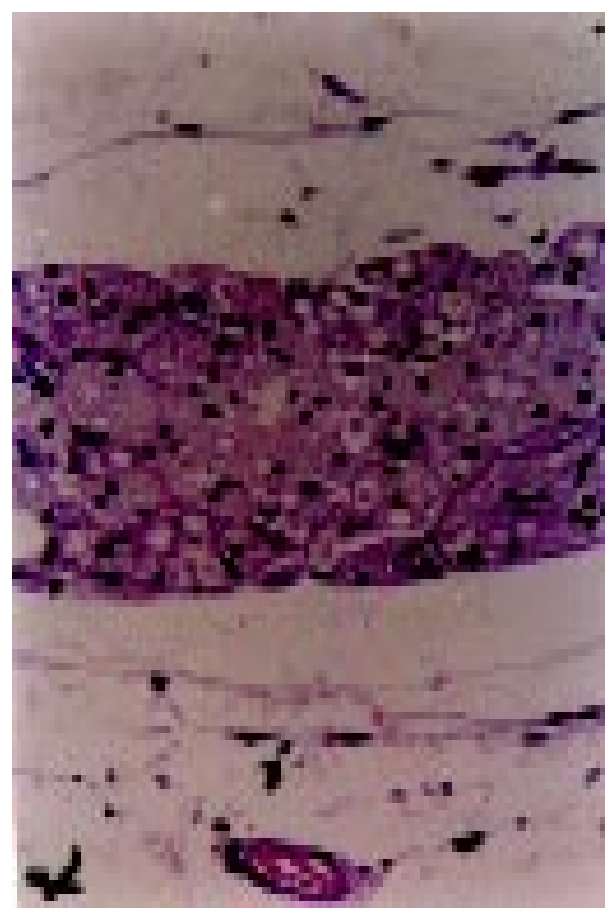

C

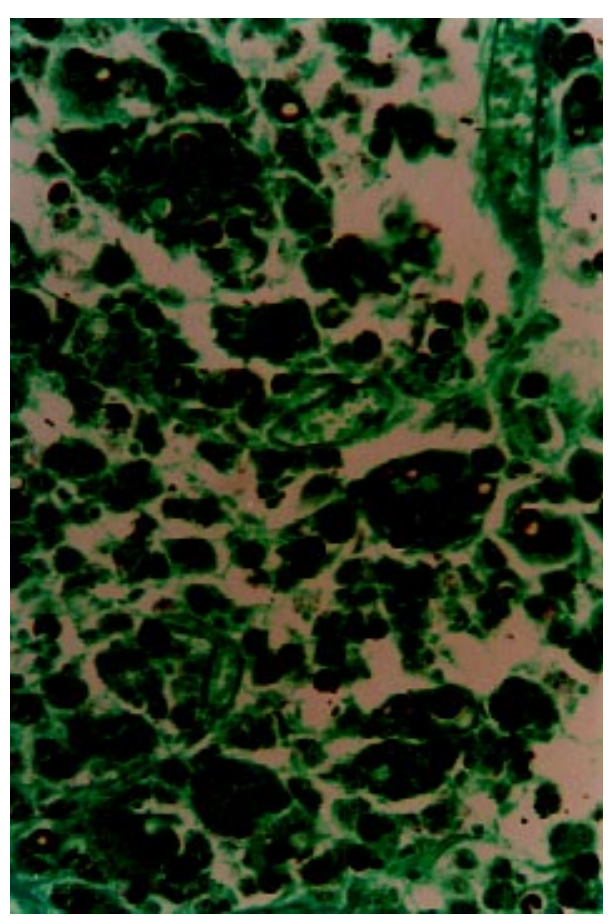

B

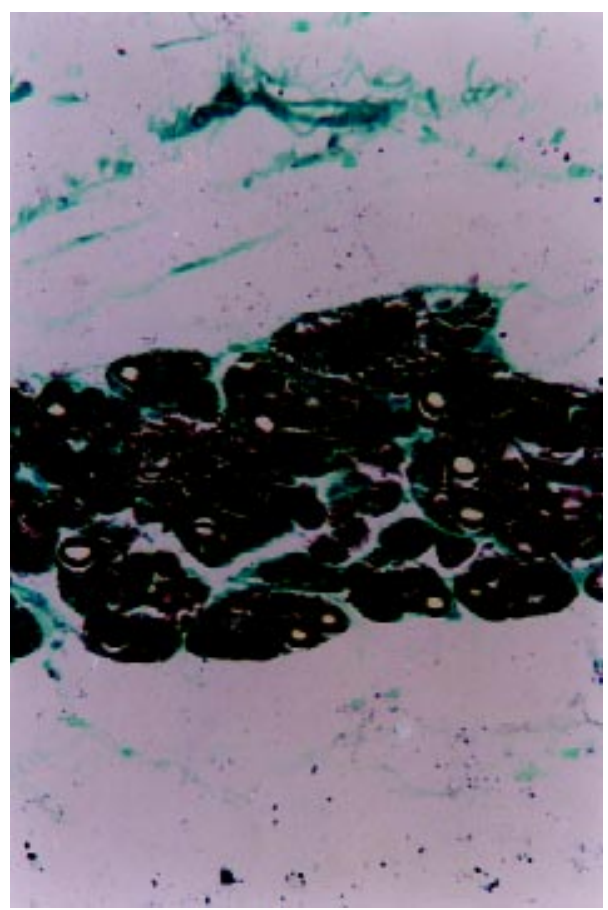

D

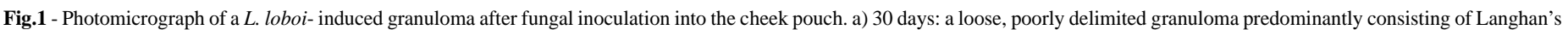

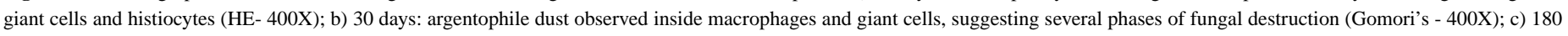

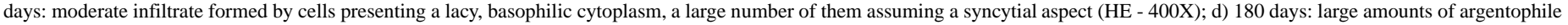
dust dispersed in the granuloma (Gomori's - 400X). 


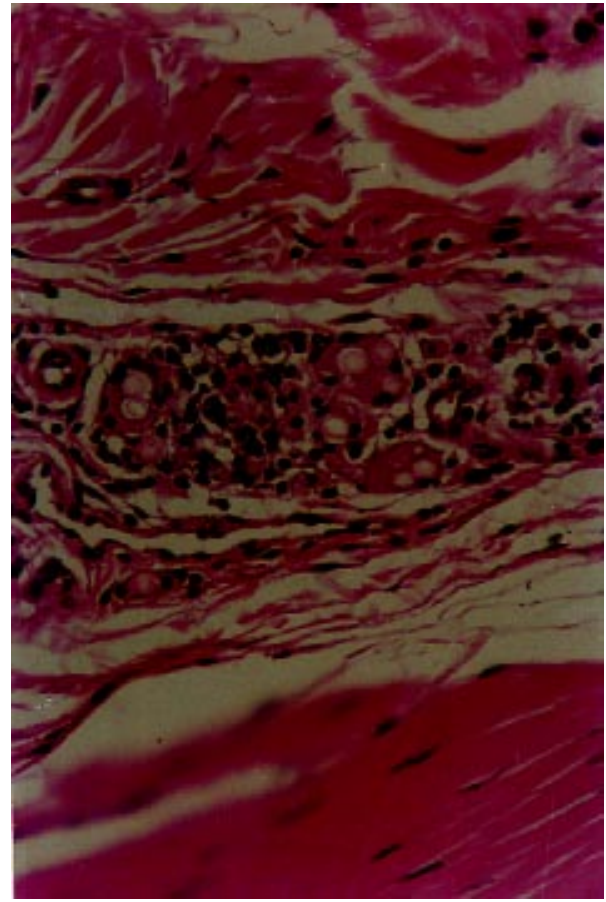

A

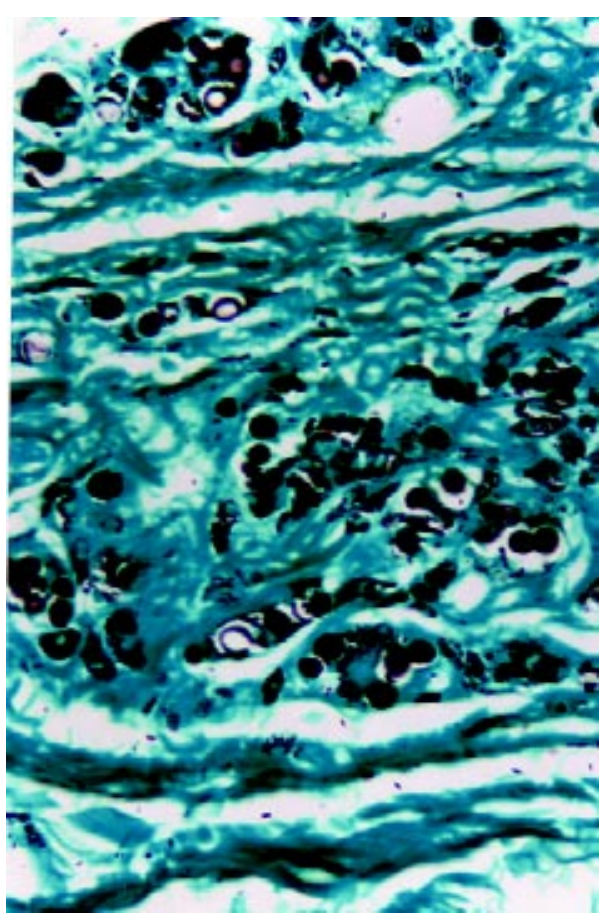

B

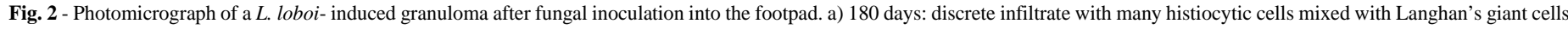
and few mononuclear cells (HE - 400X); b) 180 days: few poorly stained fungi surrounded by large quantities of argentophile dust (Gomori's $400 \mathrm{X}$ ).

that these investigators did not mention the quantity or variation in number of inoculated fungi during the experiment and no criterion of viability was adopted for these organisms. If, as a consequence, their results could be false, it is possible that our observations might also be inaccurate since we used inocula with fewer fungi than those used by these authors, making it necessary to perform our experiments using inocula with larger amounts of fungi and a better percentage of viability.

The inoculation of isolated fungi implies that the parasite must adapt itself to the hamster tissue, whereas when fragments of lesions are implanted the parasite continues to multiply in human cells. It is plausible to speculate that cells from the human lesions were grafted and not rejected by the immune system as would have happened when the fragments were implanted into the footpad. This hypothesis is under investigation.

Although we have not examined the satellite lymph nodes of infected animals, the low index of survival and multiplication of the parasite makes its dissemination unlikely. Nevertheless, SAMPAIO \& DIAS ${ }^{16}$ detected the fungi in these organs. Again, the large number of parasites in the lesions observed by the authors might be a determinant for parasite metastatization in lymphoid organs. BIJOVSKY et al. ${ }^{6}$ have demonstrated that the inoculation of Trypanosoma cruzi into subcutaneous tissue of the cheek pouch results in local retention and proliferation of the parasite. However, during longer periods of infection, the parasites infect the proximal muscle layer of the pouch where lymphatic vessels are present, allowing dissemination of the trypanosomes. The same may have occurred when fragments of lesions were implanted into the pouch by SAMPAIO \& DIAS ${ }^{16}$.

The histologic analysis of the lesions in the pouch and footpad, an immunocompetent site, yielded relevant information. It became clear that debris of dead fungi determine both in the pouch and in the footpad the persistence of the lesions for a long period of time (180 days in the footpad). This observation suggests that treatment of patients with drugs that kill the fungi may not induce prompt remission of the chronic inflammatory lesion. Another apparently paradoxical observation was that while in the cheek pouch the prevalence of cells with lacy cytoplasm, few giant cells, rare lymphocytes and non-viable fungi was observed, in the foot the infiltrate presented a higher number of foreign body giant cells, lymphocytes and viable fungi up to 60 days. These observations indicate that in the absence of an immune response the phagocytic system is more competent to eliminate fungal debris, facilitating resolution of the lesion. Conversely, the induction of an immune response when the fungus is inoculated into the footpad, involves a more reactive but less effective inflammatory response. Similar observations were made by SINHORINI et al. ${ }^{19}$ after inoculation of BCG into the subcutaneous tissue of the pouch or in the footpad. Although animals inoculated into the pouch were PPD negative, the lesions at this site tended to heal while those in the footpad did not resolve. The mechanisms that govern these differences need further investigations.

The data herein presented indicate that when isolated $L$. loboi is inoculated into the subcutaneous tissue of the hamster cheek pouch a 
limited infection occurs, thus indicating that the fungus is not adapted to infecting hamster cells even in the absence of an immune response against parasite antigens.

\section{RESUMO}

\section{Inoculação de Lacazia loboi no tecido celular subcutâneo da bolsa jugal do hamster}

O tecido celular subcutâneo da bolsa jugal do hamster, um local de privilégio imunológico, tem sido usado para a investigação da infectividade potencial de diferentes tipos de parasitas. Está demonstrado que o implante de fragmentos de lesões induzidas pelo fungo Lacazia loboi, o agente etiológico da doença de Jorge Lobo, no tecido subcutâneo da bolsa jugal do hamster resultou na multiplicação e disseminação do parasita para linfonodos satélites ${ }^{16}$. Neste trabalho, descrevemos a evolução de lesões induzidas pela inoculação do fungo isolado de lesões de humanos neste sítio de privilégio imunológico. A morfologia da resposta inflamatória, a viabilidade e proliferação do fungo foram analisadas. A inoculação do fungo na bolsa jugal induziu granulomas com raros linfócitos. Embora células fúngicas tenham sido observadas até 180 dias após inoculação, os fungos perderam viabilidade após o primeiro dia da inoculação. Contrariamente, quando o fungo foi inoculado no coxim plantar dos animais, foram observadas lesões histiocitárias não organizadas. Células gigantes do tipo Langhans, linfócitos e fungos foram observados nessas lesões. Quando inoculado na pata dos animais, a viabilidade do fungo foi observada até 60 dias após inoculação. Parasitas não viáveis foram observados em lesões de até 180 dias. Esses dados indicam que o tecido celular subcutâneo da bolsa jugal do hamster não é local adequado para a proliferação do Lacazia loboi quando o fungo isolado de tecido humano é testado.

\section{REFERENCES}

1. ALMEIDA, F.P. \& LACAZ, C.S. - Blastomicíase "tipo Jorge Lobo". Rev. paul. Med., 32: $161-162,1948$

2. ARRUDA, M.S.P.; COELHO, K.I.R. \& MONTENEGRO, M.R. - Experimental paracoccidioidomycosis in Syrian hamster inoculated in the cheek pouch. Mycopathologia (Den Haag), 128: 67-73, 1994.

3. ARRUDA, M.S.P.; FLEURY, R.N. \& NOGUEIRA, M.E.S. - Inoculation of Mycobacterium leprae into the cheek pouch. Leprosy Rev., 66: 181-182, 1995.

4. AZULAY, R.D.; ANDRADE, L.C. \& CARNEIRO, J.A. - Micose de Jorge Lobo. Contribuição ao seu estudo experimental. Inoculações no homem e animais de laboratório e investigação imunológica. Hospital (Rio de J.), 73: 167-174, 1968.

5. BARKER, F. \& BILLINGHAN, R.E. - Immunologically privileged sites. Advanc. Immunol., 25: 1-54, 1977.
6. BIJOVSKY, A.T.; MILDER, R.V.; ABRAHAMSOHN, I.A.; SINHORINI, I.L. \& MARIANO, M. - The influence of lymphatic drainage in experimental Trypanosoma cruzi infection. Acta trop. (Basel), 41: 207-214, 1984.

7. CAMPO-AASEN, I. - Nota prévia sobre el primer caso de enfermedad de Jorge Lobo ó blastomicosis queloidiana en Venezuela. Derm. venez., 1: 118- 121, 1957.

8. CAMPO-AASEN, I. - Blastomicosis queloidiana o enfermedad de Jorge Lobo en Venezuela. Derm. venez., 1: 215-240, 1958

9. GROGOTT, R.G. - A stain for fungi in tissue sections and smears, using Gomori's methenamine-silver nitrate technique. Amer. J. clin. Path., 25: 975-979, 1955.

10. LACAZ, C.S.; BARUZZI, R.G. \& ROSA, M.C.B. - Doença de Jorge Lobo. São Paulo, USP/IPSIS, 1986.

11. LILLIE, R.D. - Histopathologic technique and practical histochemistry. New York, Blakinster, 1954.

12. LOBO, J. - Um caso de blastomicose produzido por uma espécie nova encontrada em Recife. Rev. méd. Pernambuco, 1: 763-775, 1931.

13. NERY-GUIMARÃES, F. - Inoculações em hamsters da blastomicose sul-americana (doença de Lutz), da blastomicose queloidiforme (doença de Lobo) e da blastomicose dos índios do Tapajós-Xingu. Hospital (Rio de J.), 66: 127-139, 1964

14. RODRIGUEZ-TORO, G. - Lobomycosis. Int. J. Derm., 32: 324-332, 1993.

15. ROXO, E.; SINHORINI, I.L. \& MARIANO, M. - Evolução das lesões induzidas por micobactérias BCG e por $\mathrm{H}_{37} \mathrm{RV}$ em hamster (Mesocricetus auratus). Hansenol. Int., 19: 19-25, 1994.

16. SAMPAIO, M.M. \& DIAS, L.B. - Experimental infection of Jorge Lobo's disease in the cheek pouch of the golden hamster (Mesocricetus auratus). Rev. Inst. Med. trop. S. Paulo, 12: 115-120, 1970 .

17. SAMPAIO, M.M. \& DIAS, L.B. - The armadillo Euphractus sexcintus as a suitable animal for experimental studies of Jorge Lobo's disease. Rev. Inst. Med. trop. S. Paulo, 19: 215-220, 1977.

18. SAMPAIO, M.M.; DIAS, L.B. \& SCAFF, L. - Bizarre forms of the etiologic agent in experimental Jorge Lobo's disease in tortoises. Rev. Inst. Med. trop. S. Paulo, 13 192-193, 1971.

19. SINHORINI, I.F.; MERESSU, J.L. \& MARIANO, M. - Role of lymphatic drainage on the development of Calmette-Guerin bacillus-induced granulomas in the hamster. Int. Arch. Allergy Immunol., 103: 166-174, 1994.

20. TAPIA, A.; TORRES-CALCINDO, A. \& AROSEMENA, R. - Keloidal blastomycosis (Lobo's disease) in Panamá. Int. J. Derm., 17: 572-577, 1978.

21. TREJOS, A. \& ROMERO, A. - Contribución al estudio de las blastomicosis en Costa Rica. Rev. Biol. trop. (San José), 1: 63-81, 1953.

22. VILANI-MORENO, F.R. \& OPROMOLLA, D.V.A. - Determinação da viabilidade do Paracoccidioides loboi em biópsias de pacientes portadores de doença de Jorge Lobo. An. bras. Derm., 72: 433-437, 1997.

Received: 29 March 1999

Accepted: 29 March 2000 